\title{
The Possibility of Drought Risk Reduction in Corn Production
}

\author{
Nemanja Pajić · Todor Marković \\ University of Novi Sad, Faculty of Agriculture, Trg D. Obradovića 8, 21000 Novi Sad, Serbia
}

\begin{abstract}
Summary: Weather derivatives are contemporary instruments for insurance risk of drought in agricultural production. Corn production is particularly sensitive to this risk, and the amount of the yield of this crop is in significant correlation with the July-August rainfall amount. Oscillations of production output, caused by the risk of drought, are reflected directly on the fluctuations of the financial result. The application of weather derivatives may decrease the variability of the mentioned economic parameter in corn production. In the investigated example of corn production, simulating the application of the weather option the coefficient of variation of realized financial results decreased by $9.64 \%$ compared to the version without the insured risk. At the same time, using the analysed insurance instrument, the risk of achieving a negative financial result is eliminated.

Keywords: corn, drought, financial results, risk reduction, weather derivatives
\end{abstract}

\section{Introduction}

As the primary sector of the economy, agriculture has much specificity. The role of the agricultural sector in every country is securing food independence. Apart from playing its primary role, in some countries agriculture brings significant financial results and provides raw materials for industrial processing. Besides all the benefits that it provides, it is necessary to have in mind that agriculture, as any other production, bears risks that can jeopardise and lessen the expected results. In agriculture, especially in plant production, these risks are specific, as they depend on weather conditions which are practically impossible to eliminate. For these reasons, there is an obvious need for a certain system of handling the mentioned specific risk. In plant and crop production, the best instrument for that is the crop insurance.

The development of crop and fruit insurance resulted in a number of insurance systems throughout the world. Depending on the criteria, crop and fruits insurance systems can be divided in different ways. One of the most comprehensive divisions discriminates between yield insurance, success indicator insurance, whole-farm insurance, and the so called index insurance

Corresponding author:

nemanjapajic1989@gmail.com

Acknowledgements:

This study is part of the project III 46006 titled "Sustainable agriculture and rural development in order to achieve strategic goals Republic of Serbia in the Danube region" and the project TR31011 titled "Effect of components quality in cyprinids feeding on meat quality, losses and economic efficiency" subsidized by the Ministry of Education, Science and Technological Development of the Republic of Serbia.
(Marković \& Jovanović 2011). Out of all listed systems, implementation of index insurance is a pioneer enterprise of a number of institutions, with the goal to establish an appealing risk distribution between the insurer and the insured, attract new customers and further develop the insurance market.

In index insurance, weather derivatives are very important and interesting instruments for risk reduction in agricultural production (Manfredo \& Richards 2009). Weather derivatives represent relatively new financial instruments, which originated in the mid-1990s (Marković \& Jovanović 2011), and their payment is conditioned with the realized value of a weather parameter (Schmitz 2007). The mentioned financial instruments have many advantages in comparison with regular insurance, such as elimination of moral hazard, negative selection, etc. (Woodard \& Garcia 2008). Weather derivative contracts insure objective protection of production risks against quantified weather outcomes (Baojing et al. 2013). Therefore, these are the products of financial market related to temperature, precipitation and all other weather variables which can be measured objectively (Mußhoff et al. 2005).

It is necessary to mention that weather derivatives belong to the group of the so called forward contracts. These are index-based contracts in which the weather index is derived by calculating the deviation of weather parameters in relation with the reference point. If the chosen weather variable drops below or rises above the reference value (strike level), the contract becomes effective and the weather parameter becomes a product that could be the object of trade (Marković et al. 2012). 
Weather contracts can be concluded both on the organized market (stock exchange) and off-exchange, on the so called OTC (over the counter) market (banks, insurance companies), while the creation of contracts depends on the buyers' and sellers' attitude towards risk as well as on their expectations in the future (Schmitz 2007).

Since the weather derivatives on the insurance market of the Republic of Serbia are not yet available, the aim of this study was to show the possibilities of reducing the risk of drought in agricultural production, using weather derivatives. Special emphasis of the research effort has been placed on the use of the said instrument in corn production, and the assessment of the effects of its application on the movement of financial result per unit area.

\section{Material and Methods}

The necessary data for the study were collected from the company Agrohalas Ltd, Ada, Serbia. The time frame of the research is 10 years (from 2004 to 2013). The data are related to precipitation in July and August, realized yield, revenue and realized costs in certain years of the analysed period. All values are expressed in euros (EUR) as the research encompasses a 10-year period throughout which devaluation of dinar (RSD) was on a high level.

Classical statistical indicators (correlation quotient, variation quotient, and variation interval, mean) were used to reach the needed results and conclusions. The used economic parameter was financial result based on the difference between revenue and total costs. Weather option was also used as an insurance instrument, with the value of fair premium derived by the use of @Risk software. The fluctuation of financial result in corn production, with and without option, was analysed with the use of the mentioned methods.

\section{Results and Discussion}

By observing the past period, it is obvious that natural disasters and different types of adverse weather have become more and more likely to happen. These weather conditions certainly significantly affect the decrease of yield in agriculture, and with that cause great loss in agricultural production. Drought has been one of the most prominent risks in the past couple of years, decreasing the yield in crop and plant production. This is especially true for spring crops, such as corn, soy bean, sugar beet, etc.

In the situations where drought causes great damage, regular insurance can hardly be used for a precise quantification of actual losses. Therefore, the use of newer insurance systems in these situations is inevitable. If geographical and basis related production risks are excluded, a very good solution for the mentioned problem would be the use of weather derivatives. According to Berg et al. (2005), the basic types of weather derivatives are:

- Weather futures (standard contracts used for stock market trade);

- Weather forwards (private contracts used for trade on the OTC market which usually appear in the form of weather swaps);

- Weather options (used both for stock exchange and OTC market trade).

The crop which is particularly vulnerable to the mentioned risk of drought is corn. It is widely known that the yield of this agricultural crop mostly depends on the precipitation between July and August. A lower level of precipitation in the mentioned period can significantly affect the decrease in the cost-effectiveness of corn production.

Table 1. Measured precipitation and the realized corn yield in the company Agrohalas Ltd

\begin{tabular}{lcccc}
\hline Year & July $(\mathrm{mm})$ & August $(\mathrm{mm})$ & July - Aug $(\mathrm{mm})$ & Yield $\left(\mathrm{kg} \mathrm{ha}^{-1}\right)$ \\
\hline 2004 & 45.9 & 69.5 & 115.4 & 7,878 \\
2005 & 100.2 & 124.2 & 224.4 & 9,305 \\
2006 & 8.5 & 109.7 & 118.2 & 7,711 \\
2007 & 33.5 & 60.0 & 93.5 & 6,499 \\
2008 & 32.8 & 11.0 & 43.8 & 4,847 \\
2009 & 63.0 & 65.5 & 128.5 & 9,680 \\
2010 & 79.8 & 35.5 & 115.3 & 8,280 \\
2011 & 82.0 & 74.8 & 156.8 & 10,130 \\
2012 & 29.4 & 4.0 & 33.4 & 3,249 \\
2013 & 23.5 & 61.7 & 85.2 & 8,040 \\
\hline
\end{tabular}

Source: Agrohalas Ltd database 
The dependence between precipitation and the amount of the produced corn was analysed in the observed company. A significant influence of the independent variable on the dependent variable was noted. If only the effect of the amount of precipitation in July is observed, correlation quotient is $r_{x y}=0.60$. The influence of the amount of precipitation in August on corn production is also significant, and the value of the correlation quotient is $r_{x y}=0.71$. Following from this, a high level of interdependence of the total amount of precipitation in July and August and the achieved corn yield $\left(r_{x y}=0.83\right)$ is logical. During the years with less precipitation, such as 2008 and 2012, a significant decrease in yield can be noted. Drought risk causes great loss in the analysed production and can therefore stop the continuous flow of current assets, which poses a serious problem in agriculture. This problem, or risk, can be mitigated by concluding a weather contract. These contracts are a novelty in Serbia and the preposition for the structure of such a contract was given in 2014. When concluding a weather contract, it is important to make sure that its elements comply with the national legal framework, such as the Law on Banks, the Law on Investment Funds, etc. (Veselinović et al. 2014).

On the example of Agrohalas Ltd, two variants in corn production were compared: the realized financial result per year without concluded weather contracts and the financial result per year with concluded weather contracts (weather options).

The data regarding realized yield, average redemption price of corn in certain years of the analysed period, average rate of euro in the analysed years, as well as the total costs of corn production per certain years were used in order to obtain the financial result without a concluded weather option in the observed company.

Based on the data in Table 2, a great variability of financial results per certain years can be noted, which is the direct consequence of the variability of the amount of precipitation in the analysed period. Apart from that, negative financial results from 2008 and 2012 are also prominent.

The decrease of this phenomenon, and with it the decrease in the influence of drought risk, can be achieved with modern insurance instruments such as weather derivatives. Options' trading dominates the market of weather derivatives (Becker \& Bracht 1999). Therefore, the analysed example in this study will be this type of a weather derivative. Having in mind the right obtained by concluding a weather option, the difference between a call option and a put option can be made. When it comes to the situation analysed in this study, put option is interesting for the observed company as it involves a buyer who is liable to pay a premium and who also gains the payment right based on the difference between the realized weather index value and the defined strike level.

Based on the data in Table 2, a great variability of financial results per certain years can be noted, which is the direct consequence of the variability of the amount of precipitation in the analysed period. Apart from that, negative financial results from 2008 and 2012 are also prominent.

Table 2. Financial result in corn production in the company Agrohalas Ltd

\begin{tabular}{|c|c|c|c|c|c|c|}
\hline Year & $\begin{array}{l}\text { Yield } \\
\left(\mathrm{kg} \mathrm{ha}^{-1}\right)\end{array}$ & $\begin{array}{c}\text { Price } \\
\left(\text { RSD kg-1) }^{-1}\right.\end{array}$ & $\begin{array}{l}\text { Revenue } \\
\left(\text { RSD ha- }^{-1}\right)\end{array}$ & $\begin{array}{l}\text { Revenue } \\
\left(€ \mathrm{ha}^{-1}\right)\end{array}$ & $\begin{array}{l}\text { Total costs } \\
\qquad\left(€ \mathrm{ha}^{-1}\right)\end{array}$ & $\begin{array}{c}\text { Financial result } \\
\qquad\left(€ \mathrm{ha}^{-1}\right)\end{array}$ \\
\hline 2004 & 7,878 & 9.02 & 71,060 & 978 & 594 & 384 \\
\hline 2005 & 9,305 & 6.46 & 60,110 & 724 & 579 & 145 \\
\hline 2006 & 7,711 & 7.47 & 57,601 & 685 & 602 & 83 \\
\hline 2007 & 6,499 & 12.24 & 79,548 & 995 & 632 & 363 \\
\hline 2008 & 4,847 & 9.84 & 47,694 & 586 & 657 & -71 \\
\hline 2009 & 9,680 & 8.92 & 86,346 & 919 & 731 & 188 \\
\hline 2010 & 8,280 & 13.49 & 111,697 & 1.084 & 754 & 330 \\
\hline 2011 & 10,130 & 17.05 & 172,717 & 1.694 & 738 & 956 \\
\hline 2012 & 3,249 & 20.82 & 67,644 & 598 & 724 & -126 \\
\hline 2013 & 8,040 & 16.03 & 128,881 & 1.139 & 729 & 410 \\
\hline
\end{tabular}

Sources: Agrohalas Ltd database; Statistical Office of the Republic of Serbia (www.stat.gov.rs); National Bank of Serbia (www.nbs.rs) 
Table 3. An example of a weather option concluded between Agrohalas Ltd and a financial institution

\begin{tabular}{ll}
\hline Type of a derivative & Weather option \\
\hline Weather index $(\mathrm{x})$ & The amount of precipitation in the period between July 1 and August 31 \\
\hline Reference weather station & Metering station Agrohalas Ltd \\
\hline Strike level $(\mathrm{R})$ & $\begin{array}{l}\text { The average amount of precipitation for the observed period in the last } 10 \\
\text { years }(111 \mathrm{~mm})\end{array}$ \\
\hline Payment Limit & $40 \mathrm{~mm}$ \\
\hline Monetary value of the index $(\mathrm{O})$ & $2.5 € \mathrm{~mm}^{-1}$ \\
\hline Option payment $\left(\mathrm{N}_{\circ}\right)$ & $\mathrm{N}_{\mathrm{o}}=\mathrm{O}^{*}(\mathrm{R}-\mathrm{x})$ \\
\hline Option price $\left(\mathrm{P}_{\mathrm{f}}\right)$ & $54 €$ \\
\hline
\end{tabular}

Table 4. Financial results with concluded weather options

\begin{tabular}{ccccc}
\hline Year & $\begin{array}{c}\text { Financial result } \\
\text { without the option } \\
\left(€ \mathrm{ha}^{-1}\right)\end{array}$ & $\begin{array}{c}\text { Option price } \\
(\text { fair premium }) \\
(€)\end{array}$ & $\begin{array}{c}\text { Payment from the } \\
\text { option } \\
(€)\end{array}$ & $\begin{array}{c}\text { Financial result with } \\
\text { the option } \\
\left(€ \mathrm{ha}^{-1}\right)\end{array}$ \\
\hline 384 & 54 & - & 330 \\
2004 & 145 & 54 & - & 91 \\
2006 & 83 & 54 & - & 29 \\
2007 & 363 & 54 & 44 & 353 \\
2008 & -71 & 54 & - & 43 \\
2009 & 188 & 54 & - & 134 \\
2010 & 330 & 54 & - & 276 \\
2011 & 956 & 54 & 178 & 902 \\
2012 & -126 & 54 & 65 & -2 \\
\hline
\end{tabular}

The decrease of this phenomenon, and with it the decrease in the influence of drought risk, can be achieved with modern insurance instruments such as weather derivatives. Options' trading dominates the market of weather derivatives (Becker \& Bracht 1999). Therefore, the analysed example in this study will be this type of a weather derivative. Having in mind the right obtained by concluding a weather option, the difference between a call option and a put option can be made. When it comes to the situation analysed in this study, put option is interesting for the observed company as it involves a buyer who is liable to pay a premium and who also gains the payment right based on the difference between the realized weather index value and the defined strike level.

Yearly financial result with concluded weather options is obtained when the option price (fair premium) is deducted from the financial result without the concluded weather contract and the possible payment from the contract is added (Berg 2005). On the analysed example, financial results with concluded weather options per certain years are shown in Table 4.

As can be seen in Table 4, in the years with more negative financial results, with the concluded weather contract, the situation is significantly changing based on the payment which is equal to the product of the monetary value of the index $(\mathrm{O})$ and the difference between the defined strike level and the realized weather index $(\mathrm{R}-\mathrm{x})$. In the remaining analysed years, differences are also present and directly depend on the measured weather index. A more detailed comparison between the result with and without the option is given in Table 5 .

The average profit on a yearly level in the observed period amounted to $266.2 € \mathrm{ha}^{-1}$ without the option (Table 6). With the option, the average profit would be slightly lower and would amount to $257.7 € \mathrm{ha}^{-1}$ (Table 6). Therefore, with the option, the financial result lowers by $8.5 € \mathrm{ha}^{-1}$ on average is achieved. 
Table 5. Financial result per year, with and without the option

\begin{tabular}{lcc}
\hline Year & $\begin{array}{c}\text { Financial result without the option } \\
\left(€ \mathrm{ha}^{-1}\right)\end{array}$ & $\begin{array}{c}\text { Financial result with the } \\
\text { option } \\
\left(€ \mathrm{ha}^{-1}\right)\end{array}$ \\
\hline 2004 & 384 & 330 \\
2005 & 145 & 91 \\
2006 & 83 & 29 \\
2007 & 363 & 353 \\
2008 & -71 & 43 \\
2009 & 188 & 134 \\
2010 & 330 & 276 \\
2011 & 956 & 902 \\
2012 & -126 & -2 \\
2013 & 410 & 421 \\
\hline
\end{tabular}

Table 6. The analysis of financial results per year, with and without the option

\begin{tabular}{lcc}
\hline Indicators & Without the option & With the option \\
\hline Variation interval $(\min / \mathrm{max})\left(€ \mathrm{ha}^{-1}\right)$ & $-126 / 956$ & $-2 / 902$ \\
Variation quotient $(\%)$ & 115.15 & 105.51 \\
\hline Average $\left(€ \mathrm{ha}^{-1}\right)$ & 266.2 & 257.7 \\
\hline
\end{tabular}

Much more important is the fact that, with the concluded option, there is a significant decrease in variability of the achieved financial results (by 9.64\%), which is of great importance in plant and crop production, as in this way a continuous flow of financial assets is secured. This model would provide farmers with financial stability which has been harmed by multiple damages.

\section{Conclusion}

In the decade behind us, dry spells during summer months became a common occurrence which significantly affects the decrease in corn yield. To manage this risk, which has lately been the topic of many discussions, the best instruments undoubtedly are weather derivatives. The analysed example shows a great effect of July-August precipitation on corn yield $\left(r_{\mathrm{xy}}=0.83\right)$ and a high variability of yearly yield. By concluding a weather contract, oscillations of the realized financial results in corn production can be significantly decreased (by 9.64\%), and at the same time, the risk of negative financial results in each production year can be eliminated, which is of great importance for farmers. This insurance system could be exceptionally appealing to many potential policy holders. Therefore, in the following period, the implementation of this insurance system will be desirable in Serbia.

\section{References}

Baojing, S., Changhao, G., \& Van Kooten, G. C. (2013). Weather Derivatives and Crop Insurance in China. REPA, University of Victoria, Victoria.

Becker, H. A., \& Bracht, A. (1999). Katastrophen und Wetterderivate Finanzinnovationen auf der Basis von Naturkatastrophen und Wettererscheinungen. Bank Verlag, Wien.

Berg, E. (2005). Integriertes Risikomanagement - Nortwendigkeit und Konzepte für die Praxis. In: Deitmar, J. (Hrsg): Agrarökonomie im Wandel, Tagungsband anlässlich des 80. Geburtstages von Prof. em. Dr. Dr. h.c. Günther Steffen am 24. September, ILB, Bonn.

Berg, E., Schmitz, B., Starp, M., \& Trenkel, H. (2005). Wetterderivate: Ein Instrument im Risikomanagement für Landwirtschaft? Agrarwirtschaft, 54(3): 158-170.

Manfredo, M.R., \& Richards, T.J. (2009). Hedging with weather derivatives: a role for options in reducing basis risk. Applied Financial Economics, 19(2): 87-97.

Marković, T., \& Jovanović M. (2011). Uticaj količine padavina na prinos pšenice i kukuruza kao proizvodni bazni rizik. Ratar. Povrt. 48(1): 207-212.

Marković, T., Ivanović, S., \& Todorović, S. (2012). Osiguranje dobiti u proizvodnji šećerne repe primenom vremenskih derivata. Ratar. Povrt. 49(2): 146-150.

Mushoff, O., Odening, M., \& Xu, W. (2005). Zur Bewertung von Wetterderivaten als innovative Risikomanagement instrumente in der Landwirtschaft. Agrarwirtschaft, 54(4): 197-209.

Schmitz, B. (2007). Wetterderivate als Instrument im Risikomanagement landwirtschaftlicher Betriebe. Doctoral Dissertation. University of Bonn, Bonn.

Veselinović, J., Marković, T., \& Đukić, S.(2014). Analysis of Legal and Economic Aspects of Precipitation Weather Derivatives for Serbian Agricultural Sector. Ekonomika poljoprivrede, 61(4): 10531068.

Woodard, J.D., \& Garcia, P. (2008). Weather Derivatives, Spatial Aggregation, and Systemic Risk: Implications for Reinsurance Hedging. Journal of Agricultural and Resource Economics, 33(1): 34-51. 


\section{Mogućnost smanjenja rizika od suše u proizvodnji kukuruza}

\section{Nemanja Pajić. Todor Marković}

Sažetak: Vremenski derivati predstavljaju savremene instrumente za osiguranje rizika od suše u poljoprivrednoj proizvodnji. $\mathrm{Na}$ ovaj rizik naročito je osetljiva proizvodnja kukuruza, a visina prinosa ove kulture u značajnoj je korelaciji sa julsko-avgustovskim padavinama. Oscilacije proizvodnih rezultata, uslovljene rizikom suše, reflektuju se direktno i na oscilacije finansijskog rezultata. Primenom vremenskih derivata može se uticati na smanjenje varijabilnosti pomenutog ekonomskog parametara u proizvodnji kukuruza. $\mathrm{Na}$ istraživanom primeru proizvodnje kukuruza, simuliranjem primene vremenske opcije, koeficijent varijacije ostvarnih finansijkih rezultata manji je za 9,64\% u odnosu na varijantu bez osiguranog rizika. Istovremeno, upotrebom analiziranog instrumenta osiguranja, eliminiše se i rizik ostvarivanja negativnog finansijskog rezultata.

Ključne reči: finansijski rezultat, kukuruz, smanjenje rizika, suša, vremenski derivati 